\title{
Effect of $\mathrm{Mg} / \mathrm{Al}_{2} \mathrm{O}_{3}$ and Calcination Temperature on the Catalytic Decomposition of HFC-134a
}

\author{
Caroline Mercy Andrew Swamidoss ${ }^{1,2,+}$, Mahshab Sheraz ${ }^{1,+}$, Ali Anus ${ }^{1}$, Sangjae Jeong ${ }^{3}$, \\ Young-Kwon Park ${ }^{4}$, Young-Min Kim ${ }^{5, *}$ and Seungdo Kim ${ }^{1, *}$ \\ 1 Department of Environmental Sciences and Biotechnology, Hallym University, Chuncheon 24252, Korea; \\ caru.swamidoss@gmail.com (C.M.A.S.); mahshabsheraz001@gmail.com(M.S.); \\ alianuskhan@gmail.com(A.A.) \\ 2 Department of Science and Humanities, Saveetha School of Engineering, Chennai 600124, India \\ 3 Research Center for Climate Change and Energy, Hallym University, Chuncheon 24252, Korea; \\ gabrie14627@gmail.com \\ 4 School of Environmental Engineering, University of Seoul, Seoul 02504, Korea; catalica@uos.ac.kr \\ 5 Department of Environmental Engineering, Daegu University, Gyeongsan 38453, Korea \\ * Correspondence: ymk@daegu.ac.kr (Y.-M.K.); sdkim@hallym.ac.kr (S.K.); Tel.: +82-53-850-6694 (Y.-M.K.); \\ +82-33-248-2165 (S.K.); Fax: +82-53-550-6699 (Y.-M.K.); +82-33-248-3285 (S.K.) \\ + These authors contributed equally to this work.
}

Received: 3 February 2019; Accepted: 11 March 2019; Published: 16 March 2019

check for updates

\begin{abstract}
This paper evaluated the effect of calcination temperature and the use of $\mathrm{Mg} / \mathrm{Al}_{2} \mathrm{O}_{3}$ on the decomposition of HFC-134a. Two commercialized catalysts, $\mathrm{Al}_{2} \mathrm{O}_{3}$ and $\mathrm{Mg} / \mathrm{Al}_{2} \mathrm{O}_{3}$, were calcined at two different temperatures $\left(500\right.$ and $650{ }^{\circ} \mathrm{C}$ ) and their physicochemical characteristics were examined by X-ray diffraction, Brunauer-Emmett-Teller analysis, and the temperature-programed desorption of ammonia and carbon dioxide analysis. The results show that, in comparison to $\mathrm{Al}_{2} \mathrm{O}_{3}, 5 \% \mathrm{Mg} / \mathrm{Al}_{2} \mathrm{O}_{3}$ exhibited a larger Brunauer-Emmett-Teller surface area and higher acidity. The relative amount of strong acid sites of the catalysts decreased with increasing calcination temperature. Although a more than $90 \%$ decomposition rate of HFC-134a was achieved over all catalysts during the sequential decomposition test of HFC-134a using a vertical plug flow reactor connected directly to a gas chromatography/mass spectrometry system, the lifetime of the catalyst differed according to the catalyst type. Compared to $\mathrm{Al}_{2} \mathrm{O}_{3}, \mathrm{Mg} / \mathrm{Al}_{2} \mathrm{O}_{3}$ revealed a longer lifetime and less coke formation due to the increased Brunauer-Emmett-Teller surface area and weak Lewis acid sites and basic sites arising from $\mathrm{Mg}$ impregnation. Higher temperature calcination extended the catalyst lifetime with the formation of less coke due to the smaller number of strong acid sites, which can lead to severe coke formation. A valuable by-product, trifluoroethylene, was formed as a result of the decomposition. Based on the experimental results, a reaction is proposed which reasonably explains the decomposition reaction.
\end{abstract}

Keywords: catalytic pyrolysis; $\mathrm{HFC}-134 \mathrm{a} ; \mathrm{Mg} / \mathrm{Al}_{2} \mathrm{O}_{3}$; calcination temperature

\section{Introduction}

Rapid global warming and climate change in recent decades and the increased frequency and impact of environmental disasters, such as global warming, sea level rises, heat, drought, and floods, have raised global interest in greenhouse gases [1,2]. Although greenhouse gases, such as $\mathrm{CO}_{2}, \mathrm{CH}_{4}$, $\mathrm{N}_{2} \mathrm{O}$, and $\mathrm{O}_{3}$, are produced naturally, their concentrations have increased due to human activity [3]. Among the various kinds of greenhouse gases, fluorinated greenhouse gases are not only synthesized and emitted by human activity but also have a much higher global warming potential (GWP) than other greenhouse gases [4]. Therefore, many studies have focused on minimizing use, recycling, 
and direct destruction of these fluorinated greenhouse gases [5]. After the Montreal Protocol, the use of chlorofluorocarbons as refrigerants was banned and hydrofluorocarbons (HFCs) have since been used as substitutes [6]. Among the various kinds of HFCs, 1,1,1,2-tetrafluoroethane (HFC-134a) is the most widely used coolant for air conditioners, but its GWP value is also very high, 1300 times higher than $\mathrm{CO}_{2}$ [7]. The seriousness of HFC-134a was highlighted in the Kyoto Protocol [8] and a decision was made to reduce its usage in the Kigali Amendment to the Montreal Protocol [9].

Various technologies have been used to minimize HFC-134a emissions, including recycling after purification using polymeric membranes [10] and the direct destruction of waste HFC-134a. Although HFC-134a can be purified using membrane technologies, their technical and economical limitations are difficult to overcome due to the high cost [11] in achieving the target HFC purity required for reuse. Therefore, many studies have considered the direct destruction [12] of HFC-134a instead. The direct destruction of HFC-134a can be achieved by applying thermal conversion technologies, such as incineration, plasma, and pyrolysis. In the case of incineration, combustion in air and ancillary fuels has been introduced, but the additional fuel input cost and equipment corrosion due to excessive HF generation are recognized as problems [13]. Steam plasma is a technology that has high HFC-134a decomposition efficiency [14], but plant enlargement is difficult due to corrosion, probably caused by the high HF concentration in the product gas, and unstable plasma discharge due to the use of steam. The high cost of plasma plant construction and its operation limit its actual commercialization. Pyrolysis can be considered as a favorable process for the decomposition of HFC-134a, but an excessively high temperature $\left(>750{ }^{\circ} \mathrm{C}\right)$ is required because of its high thermal stability [15]. Recently, many researchers have reported the catalytic pyrolysis of HFC-134a because of the lower decomposition temperatures. $\mathrm{Ni} / \mathrm{Al}_{2} \mathrm{O}_{3}$ [16], waste concrete [15], and metal phosphate catalysts [17] have been used. Han et al. [18] compared the HFC-134a decomposition efficiencies of metal oxides, such as $\mathrm{CaO}$ and $\mathrm{Al}_{2} \mathrm{O}_{3}$. They reported the highest decomposition efficiency of HFC-134a over $\mathrm{Al}_{2} \mathrm{O}_{3}$, but the rapid deactivation of $\mathrm{Al}_{2} \mathrm{O}_{3}$ by its conversion to $\mathrm{AlF}_{3}$ limits its use.

Many studies have applied metal-impregnated $\mathrm{Al}_{2} \mathrm{O}_{3}$ to increase the overall lifetime of the catalyst for the decomposition of fluorinated hydrocarbons. Han et al. [19] reported that the decomposition tendency for trifluoromethane and the stability of the substrate could be increased by metal impregnation onto $\mathrm{Al}_{2} \mathrm{O}_{3}$. Song et al. [20] achieved a high level of $\mathrm{CF}_{4}$ hydrolytic decomposition over metal-supported $\mathrm{Al}_{2} \mathrm{O}_{3}$ and explained that the catalyst modified by metal impregnation can preserve the Lewis acid sites of the catalyst, which can act as a strong active site for the decomposition of $\mathrm{CF}_{4}$. Li et al. reported the use of a metal-supported catalyst for the catalytic decomposition of HFC-143a [21]. They explained that metal phosphates can provide a more stable decomposition efficiency of fluorinated hydrocarbons due to the presence of weak acidic sites and dehydrofluorination proceeds via a carbonium-ion mechanism. Previous studies on the use of metal-supported catalysts for the decomposition of other fluorinated hydrocarbons suggested that the catalytic efficiency of $\mathrm{Al}_{2} \mathrm{O}_{3}$ can be increased and become more stable by metal impregnation, but there has been little systematic research on its use for HFC-134a decomposition.

Therefore, this study examined the catalytic decomposition of HFC-134a over Mg-supported $\mathrm{Al}_{2} \mathrm{O}_{3}\left(\mathrm{Mg} / \mathrm{Al}_{2} \mathrm{O}_{3}\right) \cdot \mathrm{Al}_{2} \mathrm{O}_{3}$ ( $\gamma$-phase) and $\mathrm{Mg} / \mathrm{Al}_{2} \mathrm{O}_{3}(\gamma$-phase) were used throughout the experimental investigation. The physicochemical properties (pore size, acidity, and structure) of $\mathrm{Al}_{2} \mathrm{O}_{3}$ and $\mathrm{Mg} / \mathrm{Al}_{2} \mathrm{O}_{3}$, which was calcined at different temperatures (500 and $650{ }^{\circ} \mathrm{C}$ ), were analyzed using Brunauer-Emmett-Teller (BET), ammonia-temperature programmed desorption ( $\left.\mathrm{NH}_{3}-\mathrm{TPD}\right)$, and carbon dioxide-temperature programmed desorption $\left(\mathrm{CO}_{2}-\mathrm{TPD}\right)$, and X-ray diffraction (XRD) measurements. The lifetime of each catalyst during the sequential decomposition of HFC-134a was estimated using vertical plug flow reactor-gas chromatography/mass spectrometry (VPFR-GC/MS). 


\section{Results}

\section{Physicochemical Properties of Catalysts}

The BET surface areas of the $\mathrm{Mg} / \mathrm{Al}_{2} \mathrm{O}_{3}$ catalysts $\left(246 \mathrm{~m}^{2} / \mathrm{g}\right.$ for $\mathrm{Mg} / \mathrm{Al}_{2} \mathrm{O}_{3}-500$ and $227 \mathrm{~m}^{2} / \mathrm{g}$ for $\left.\mathrm{Mg} / \mathrm{Al}_{2} \mathrm{O}_{3}-650\right)$ were larger than those of the $\mathrm{Al}_{2} \mathrm{O}_{3}$ catalysts $\left(139 \mathrm{~m}^{2} / \mathrm{g}\right.$ for $\mathrm{Al}_{2} \mathrm{O}_{3}-500$ and $140 \mathrm{~m}^{2} / \mathrm{g}$ for $\mathrm{Al}_{2} \mathrm{O}_{3}-650$ ). This suggests that the $\mathrm{BET}$ surface area of $\mathrm{Al}_{2} \mathrm{O}_{3}$ increased due to $\mathrm{Mg}$ impregnation. Figure 1 and Table 1 show the $\mathrm{NH}_{3}$-TPD curves and amounts of weak, moderate, and strong acid sites of $\mathrm{Al}_{2} \mathrm{O}_{3}$ and $\mathrm{Mg} / \mathrm{Al}_{2} \mathrm{O}_{3}$ catalysts, respectively. $\mathrm{Mg} / \mathrm{Al}_{2} \mathrm{O}_{3}-500$ and $\mathrm{Mg} / \mathrm{Al}_{2} \mathrm{O}_{3}-650$ had much higher weak acid amounts than $\mathrm{Al}_{2} \mathrm{O}_{3}-500$ and $\mathrm{Al}_{2} \mathrm{O}_{3}-650$, respectively. This suggests that the weak acidity of $\mathrm{Al}_{2} \mathrm{O}_{3}$ catalysts was increased by $\mathrm{Mg}$ impregnation. Jeon et al. [22,23] also reported that the addition of $\mathrm{Mg}$ increased weak Lewis acidity. Therefore, it can be concluded that weak Lewis acidity was increased with the addition of $\mathrm{Mg}$ to $\mathrm{Al}_{2} \mathrm{O}_{3}$.

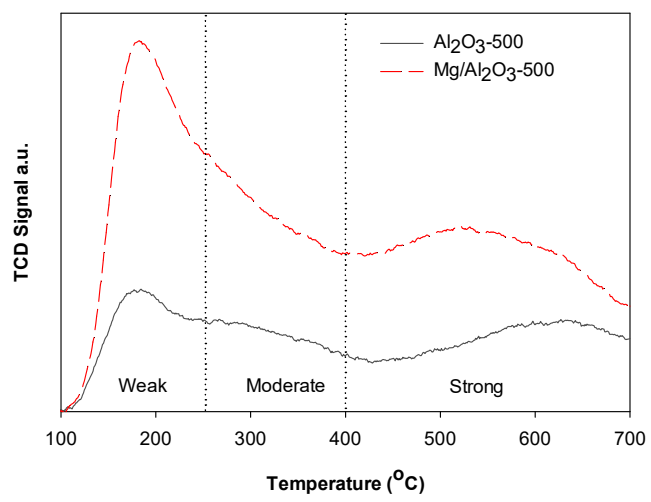

(a) $500{ }^{\circ} \mathrm{C}$

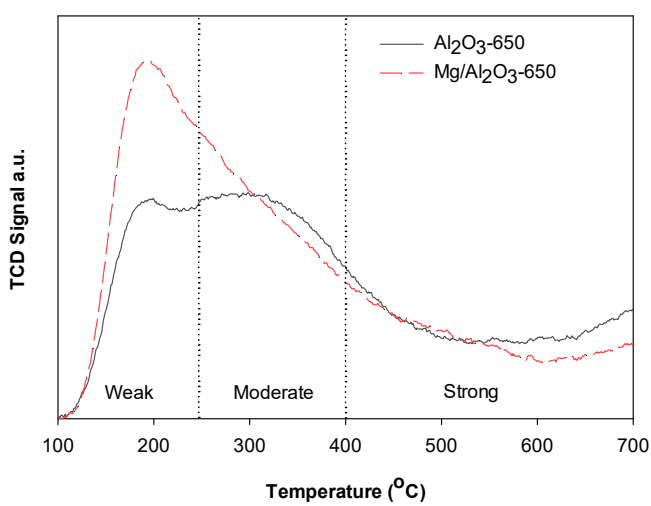

(b) $650^{\circ} \mathrm{C}$

Figure 1. Ammonia-temperature programmed desorption ( $\mathrm{NH}_{3}$-TPD) curves of $\mathrm{Al}_{2} \mathrm{O}_{3}$ and $\mathrm{Mg} / \mathrm{Al}_{2} \mathrm{O}_{3}$ calcined at different temperatures-500 and $650^{\circ} \mathrm{C}$.

Table 1. Amounts of acidic sites $\left(\mathrm{mmol} \mathrm{g}^{-1}\right)$ of each catalyst obtained from $\mathrm{NH}_{3}-\mathrm{TPD}$ analysis.

\begin{tabular}{cccccc}
\hline Catalyst & $\begin{array}{c}\text { Weak Acid } \\
\text { Amount }\end{array}$ & $\begin{array}{c}\text { Moderate Acid } \\
\text { Amount }\end{array}$ & $\begin{array}{c}\text { Strong Acid } \\
\text { Amount }\end{array}$ & $\begin{array}{c}\text { Total Acid } \\
\text { Amount }\end{array}$ & $\begin{array}{c}\text { Weak Acid } \\
\text { Amount/Strong } \\
\text { Acid Amount }\end{array}$ \\
\hline $\mathrm{Al}_{2} \mathrm{O}_{3}-500$ & 0.26 & 0.25 & 0.47 & 0.98 & 0.55 \\
$\mathrm{Mg} / \mathrm{Al}_{2} \mathrm{O}_{3}-500$ & 0.77 & 0.66 & 1.06 & 2.49 & 0.73 \\
$\mathrm{Al}_{2} \mathrm{O}_{3}-650$ & 0.23 & 0.33 & 0.29 & 0.86 & 0.79 \\
$\mathrm{Mg} / \mathrm{Al}_{2} \mathrm{O}_{3}-650$ & 0.65 & 0.59 & 0.47 & 1.70 & 1.38 \\
\hline
\end{tabular}

In addition, both $\mathrm{Al}_{2} \mathrm{O}_{3}-650$ and $\mathrm{Mg} / \mathrm{Al}_{2} \mathrm{O}_{3}-650$ revealed a smaller number of acid sites than $\mathrm{Al}_{2} \mathrm{O}_{3}-500$ and $\mathrm{Mg} / \mathrm{Al}_{2} \mathrm{O}_{3}-500$, respectively. In particular, $\mathrm{Al}_{2} \mathrm{O}_{3}-650$ and $\mathrm{Mg} / \mathrm{Al}_{2} \mathrm{O}_{3}-650$ had fewer strong acid sites than $\mathrm{Al}_{2} \mathrm{O}_{3}-500$ and $\mathrm{Mg} / \mathrm{Al}_{2} \mathrm{O}_{3}-500$, respectively. This indicates that the calcination of $\mathrm{Al}_{2} \mathrm{O}_{3}$ and $\mathrm{Mg} / \mathrm{Al}_{2} \mathrm{O}_{3}$ at higher temperatures $\left(650^{\circ} \mathrm{C}\right)$ can lead to a decrease in the number of strong acid sites [24]. The relative ratio of weak acidity/strong acidity was increased with $\mathrm{Mg}$ impregnation and the increase of calcination temperature.

The $\mathrm{CO}_{2}$-TPD curves of $\mathrm{Al}_{2} \mathrm{O}_{3}$ and $\mathrm{Mg} / \mathrm{Al}_{2} \mathrm{O}_{3}$ catalysts are shown in Figure $\mathrm{S} 1$ (Supplementary Information). $\mathrm{Mg} / \mathrm{Al}_{2} \mathrm{O}_{3}-500$ and $\mathrm{Mg} / \mathrm{Al}_{2} \mathrm{O}_{3}-650$ showed higher basicity than $\mathrm{Al}_{2} \mathrm{O}_{3}-500$ and $\mathrm{Al}_{2} \mathrm{O}_{3}-650$, suggesting that basicity increased by $\mathrm{Mg}$ impregnation. In addition, both $\mathrm{Al}_{2} \mathrm{O}_{3}-650$ and $\mathrm{Mg} / \mathrm{Al}_{2} \mathrm{O}_{3}-650$ revealed a higher number of weak basic sites and a smaller number of strong basic sites than $\mathrm{Al}_{2} \mathrm{O}_{3}-500$ and $\mathrm{Mg} / \mathrm{Al}_{2} \mathrm{O}_{3}-500$, respectively. The $\mathrm{NH}_{3}$ - and $\mathrm{CO}_{2}-\mathrm{TPD}$ results suggest that calcination of $\mathrm{Al}_{2} \mathrm{O}_{3}$ and $\mathrm{Mg} / \mathrm{Al}_{2} \mathrm{O}_{3}$ at higher temperatures $\left(650{ }^{\circ} \mathrm{C}\right)$ can lead to an increase in the number of weak acidic and basic sites and a decrease in the number of strong acidic and basic sites. The well-balanced weak Lewis acidity and basicity may affect catalytic decomposition of HFC-134a. 
Figure 2 shows XRD patterns of the $\mathrm{Al}_{2} \mathrm{O}_{3}$ and $\mathrm{Mg} / \mathrm{Al}_{2} \mathrm{O}_{3}$ catalysts calcined at different temperatures. The XRD pattern of $\mathrm{Al}_{2} \mathrm{O}_{3}$ and $\mathrm{Mg} / \mathrm{Al}_{2} \mathrm{O}_{3}$ catalysts had the characteristic broad peaks of $\mathrm{Al}_{2} \mathrm{O}_{3}$, representing the $\gamma$ phase, at $46.6^{\circ}, 67.1^{\circ}$, and $60.9^{\circ} 2 \theta$ (JCPDS 29-63). On the other hand, the peaks could be differentiated by their intensities, as reported elsewhere [25]. The intensity of the line depends on the elemental composition; hence, the impregnation of magnesium onto alumina reduced the intensity of the peaks compared with those of the $\mathrm{Al}_{2} \mathrm{O}_{3}$ catalysts [26,27]. The typical XRD peaks of $\mathrm{Mg}$ particles were barely observed in the XRD pattern of $\mathrm{Mg} / \mathrm{Al}_{2} \mathrm{O}_{3}$ catalysts. This suggests that $\mathrm{Mg}$ had penetrated into the substitutional sites of the Al lattice. Compared with the XRD peaks of $\mathrm{Al}_{2} \mathrm{O}_{3}$ catalysts, those of $\mathrm{Mg} / \mathrm{Al}_{2} \mathrm{O}_{3}$ catalysts had broader peaks and their $2 \theta$ values were shifted to slightly lower values. Wagih [28] reported that the $2 \theta$ shift of the Al peak on the XRD pattern of $\mathrm{Mg} / \mathrm{Al}_{2} \mathrm{O}_{3}$ occurs due to $\mathrm{Mg}$ atomic penetration into the $\mathrm{Al}$ matrix. $\mathrm{Mg}^{2+}$ ions with a larger ionic radius $(86 \mathrm{pm})$ than $\mathrm{Al}^{3+}(67.5 \mathrm{pm})$ are believed to have entered the alumina lattice because the shift was slight and no secondary phases were observed. Other researchers [29] support these observations. An increase in the calcination temperature resulted in an increase in peak height [30], with magnesium-doped alumina calcined at $650{ }^{\circ} \mathrm{C}$ showing an intense peak compared with its equivalent calcined at $500^{\circ} \mathrm{C}$. This was attributed to a slight change in crystallinity that modified the surface morphology. Therefore, the larger BET surface area and higher number of weak acidic sites of $\mathrm{Mg} / \mathrm{Al}_{2} \mathrm{O}_{3}$ than those of $\mathrm{Al}_{2} \mathrm{O}_{3}$ resulted from a structural change of $\mathrm{Al}_{2} \mathrm{O}_{3}$ caused by the atomic penetration of $\mathrm{Mg}$ into the substitutional sites of the Al lattice.

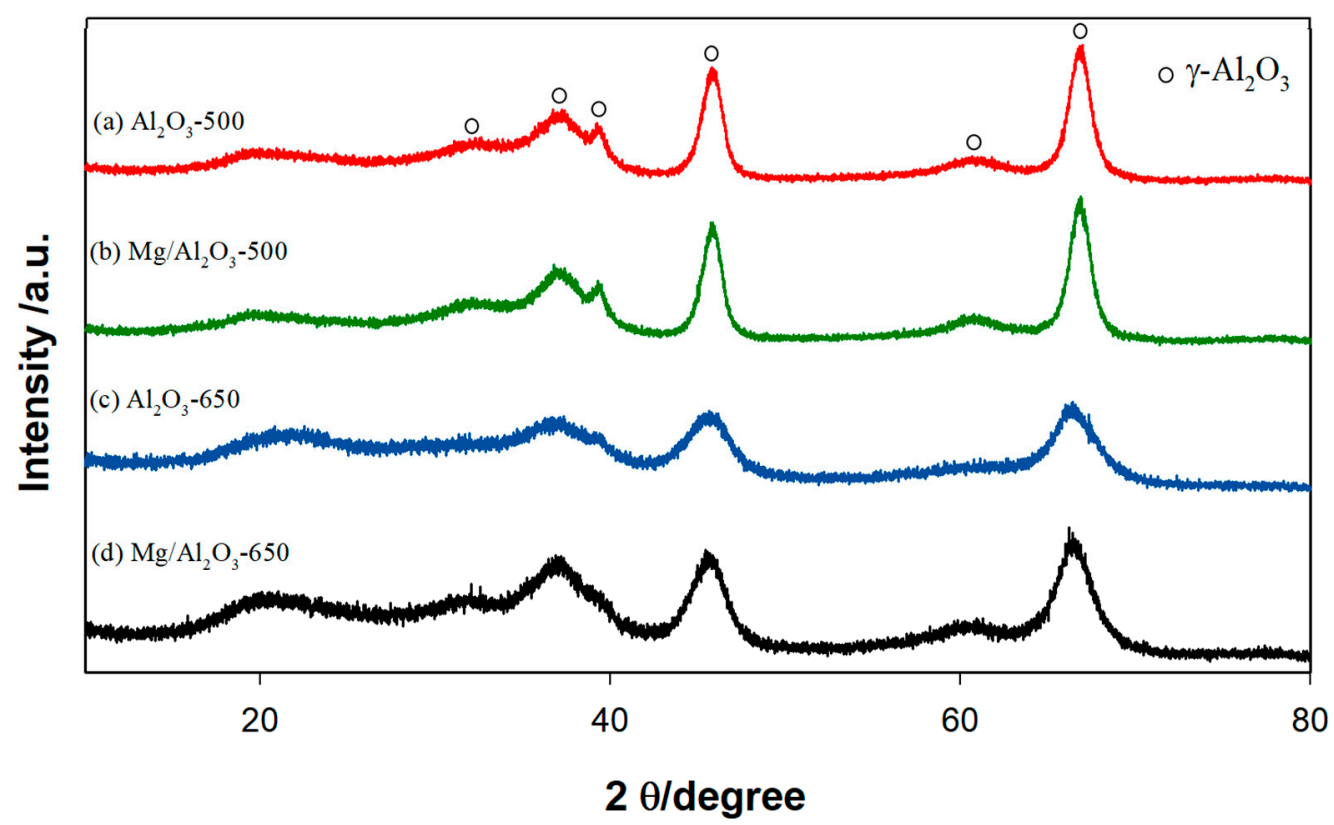

Figure 2. X-ray diffraction (XRD) pattern for $\mathrm{Al}_{2} \mathrm{O}_{3}$ and $\mathrm{Mg} / \mathrm{Al}_{2} \mathrm{O}_{3}$ calcined at different temperatures.

\section{Discussion}

\section{Catalytic Decomposition of HFC-134a}

Figure 3 depicts the conversion rates of HFC-134a obtained from the catalytic decomposition over $\mathrm{Al}_{2} \mathrm{O}_{3}$ and $\mathrm{Mg} / \mathrm{Al}_{2} \mathrm{O}_{3}$ catalysts at $600{ }^{\circ} \mathrm{C}$. Although HFC-134a was not decomposed by noncatalytic decomposition, the initial decomposition rates of HFC-134a over both catalysts were higher than 99.0\%. lizuka et al. [15] also indicated that temperatures higher than $750{ }^{\circ} \mathrm{C}$, which are required for the noncatalytic decomposition of HFC-134a, could be decreased using an $\mathrm{Al}_{2} \mathrm{O}_{3}$ catalyst. The high decomposition rates of HFC-134a (>99\%) were maintained for more than $6 \mathrm{~h}$ over all catalysts used in this study, but they decreased depending on the catalyst. 


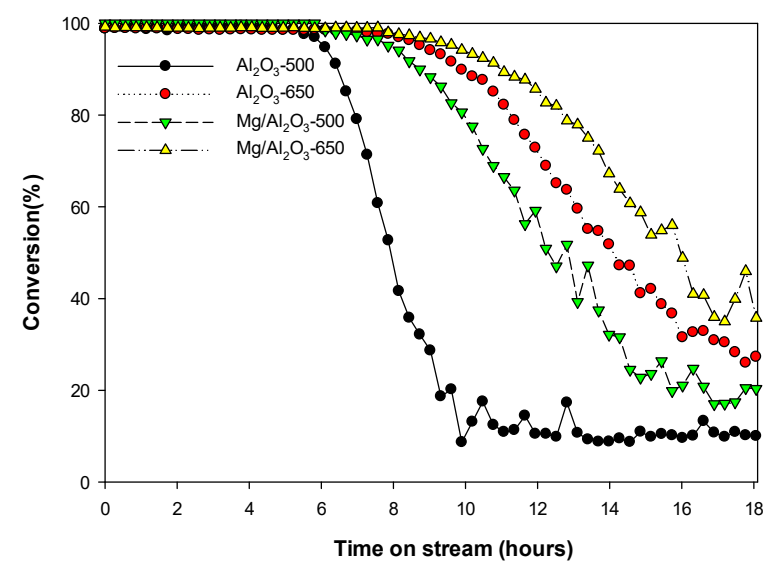

Figure 3. Conversion rate of 1,1,1,2-tetrafluoroethane (HFC-134a) over different catalysts calcined at different temperatures-500 and $650{ }^{\circ} \mathrm{C}$.

$\mathrm{Mg} / \mathrm{Al}_{2} \mathrm{O}_{3}$ decomposed HFC-134a for a longer time than $\mathrm{Al}_{2} \mathrm{O}_{3}$. This suggests that the $\mathrm{Mg}$ impregnated on the surface of $\mathrm{Al}_{2} \mathrm{O}_{3}$ might play a crucial role in the decomposition reaction of HFC-134a. The larger BET surface area, higher amount of weak Lewis acid sites, and higher amount of weak basicity of $\mathrm{Mg} / \mathrm{Al}_{2} \mathrm{O}_{3}$ catalysts than $\mathrm{Al}_{2} \mathrm{O}_{3}$ catalysts can also increase the catalyst lifetime for the decomposition of HFC-134a. These findings are in accordance with other studies reporting that a larger surface area allows better mass transfer, which facilitates a better opportunity for the catalyst to contact with the fluorinated gases [31,32].

In addition, the catalysts calcined at $650{ }^{\circ} \mathrm{C}, \mathrm{Al}_{2} \mathrm{O}_{3}-650$ and $\mathrm{Mg} / \mathrm{Al}_{2} \mathrm{O}_{3}-650$, also showed a longer lifetime than $\mathrm{Al}_{2} \mathrm{O}_{3}-500$ and $\mathrm{Mg} / \mathrm{Al}_{2} \mathrm{O}_{3}-500$ in terms of the catalytic decomposition of HFC-134a. The BET surface areas of $\mathrm{Al}_{2} \mathrm{O}_{3}-650$ and $\mathrm{Mg} / \mathrm{Al}_{2} \mathrm{O}_{3}-650$ were similar, respectively, to those of $\mathrm{Al}_{2} \mathrm{O}_{3}-500$ and $\mathrm{Mg} / \mathrm{Al}_{2} \mathrm{O}_{3}-500$. In addition, the total acidity of $\mathrm{Al}_{2} \mathrm{O}_{3}$ and $\mathrm{Mg} / \mathrm{Al}_{2} \mathrm{O}_{3}$ decreased with the increasing catalyst calcination temperature. The decrease in the number of strong acid sites on the catalysts calcined at $650{ }^{\circ} \mathrm{C}$ was the main factor increasing the lifetime of $\mathrm{Al}_{2} \mathrm{O}_{3}$ and $\mathrm{Mg} / \mathrm{Al}_{2} \mathrm{O}_{3}$. Jia et al. [33] reported that the strong acid sites of $\mathrm{Al}_{2} \mathrm{O}_{3}$ led to higher coke formation, which can decrease the catalyst lifetime. Especially, the catalytic activities were well correlated with the ratio of weak acidic sites/strong acidic sites (Table 1). The increase of weak basic sites and a decrease of strong basic sites on the catalysts calcined at $650{ }^{\circ} \mathrm{C}$ can also be an important factor in increasing the lifetime of $\mathrm{Al}_{2} \mathrm{O}_{3}$ and $\mathrm{Mg} / \mathrm{Al}_{2} \mathrm{O}_{3}$.

Figure 4 shows the rate of trifluoroethylene $\left(\mathrm{TrFE}, \mathrm{C}_{2} \mathrm{HF}_{3}\right)$ formation through the catalytic decomposition of HFC-134a over the $\mathrm{Al}_{2} \mathrm{O}_{3}$ and $\mathrm{Mg} / \mathrm{Al}_{2} \mathrm{O}_{3}$ catalysts calcined at different temperatures. Compared with the $\mathrm{Al}_{2} \mathrm{O}_{3}$ catalysts, $\mathrm{Mg} / \mathrm{Al}_{2} \mathrm{O}_{3}$ catalysts produced a larger amount of TrFE for a longer duration. In addition, the catalysts calcined at $650{ }^{\circ} \mathrm{C}$ produced a larger amount of $\operatorname{TrFE}$ than those calcined at $500{ }^{\circ} \mathrm{C}$. This suggests that $\mathrm{Mg}$ impregnation and calcination at $650{ }^{\circ} \mathrm{C}$ can increase the catalyst lifetime not only for the decomposition of HFC-134a but also for the formation of TrFE. The efficient formation of TrFE is desirable because it is a significant feedstock for the synthesis of fluoroplastics and fluororubbers [16,33]. TrFE can be generated through hydrolysis of trichlorotrifluoroethane, but this is a difficult and an expensive process [34-37]. Therefore, efficient TrFE formation via the catalytic decomposition of HFC-134a over $\mathrm{Mg} / \mathrm{Al}_{2} \mathrm{O}_{3}$ is meaningful because of its cost effectiveness.

Figure 5 shows the oxidative TG and DTG curves of deactivated catalysts collected after the sequential decomposition of HFC-134a. The catalytic decomposition of HFC-134a over $\mathrm{Mg} / \mathrm{Al}_{2} \mathrm{O}_{3}-650$ formed the smallest amount of coke $(3.7 \% \pm 1 \%)$ followed in order by $\mathrm{Mg} / \mathrm{Al}_{2} \mathrm{O}_{3}-500(3.9 \% \pm 1 \%)$, $\mathrm{Al}_{2} \mathrm{O}_{3}-650(11.9 \% \pm 1 \%)$, and $\mathrm{Al}_{2} \mathrm{O}_{3}-500(16.0 \% \pm 1 \%)$, which is in the order of the HFC- $134 \mathrm{a}$ decomposition efficiency of these catalysts. This suggests that the decomposition efficiency and catalyst lifetime are also strongly related to the amount of coke formed during the catalytic decomposition of 
HFC-134a. The $\mathrm{Mg} / \mathrm{Al}_{2} \mathrm{O}_{3}$ catalysts produced a smaller amount of coke and the oxidation temperatures of the coke deposited on the $\mathrm{Mg} / \mathrm{Al}_{2} \mathrm{O}_{3}$ catalysts were also lower than those deposited on $\mathrm{Al}_{2} \mathrm{O}_{3}$ catalysts. This means that the use of $\mathrm{Mg} / \mathrm{Al}_{2} \mathrm{O}_{3}$ catalysts can provide higher decomposition efficiency for a longer duration than $\mathrm{Al}_{2} \mathrm{O}_{3}$ catalysts because of the small amount of coke deposition having a lower oxidation temperature.

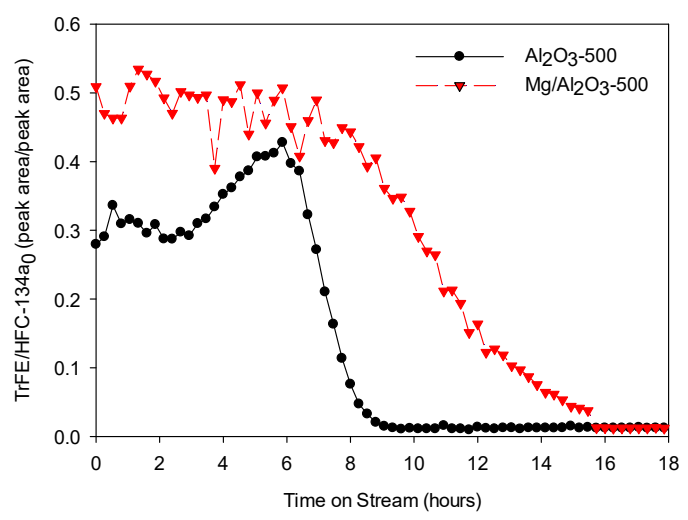

(a) $500{ }^{\circ} \mathrm{C}$

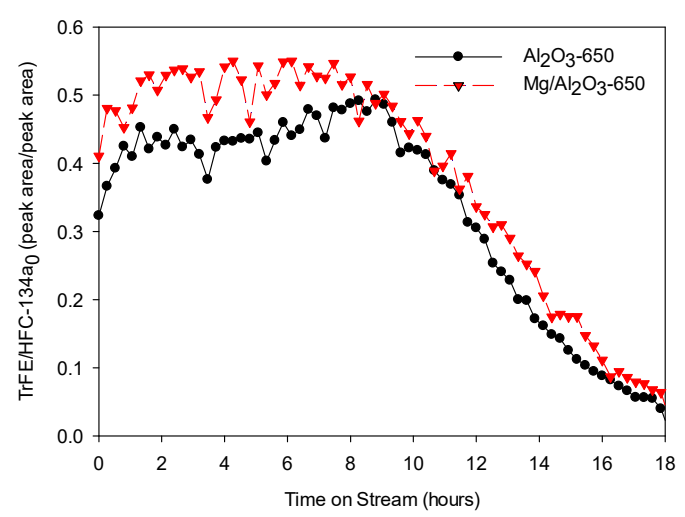

(b) $650{ }^{\circ} \mathrm{C}$

Figure 4. Formation rate of trifluoroethylene (TrFE) on the catalytic decomposition of HFC-134a over different catalysts calcined at different temperatures-500 and $650{ }^{\circ} \mathrm{C}$.

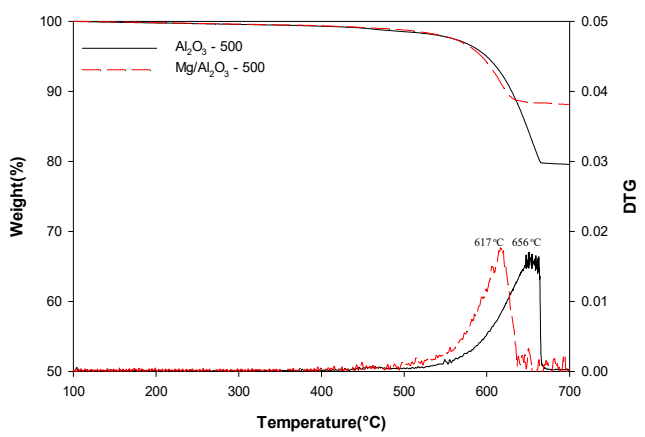

(a) $500{ }^{\circ} \mathrm{C}$

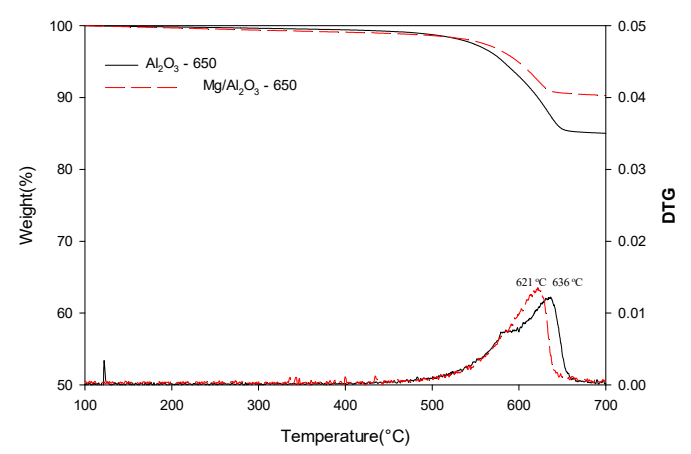

(b) $650{ }^{\circ} \mathrm{C}$

Figure 5. Oxidative Differential Thermogravimetric (DTG) curves of the coke deposited on $\mathrm{Al}_{2} \mathrm{O}_{3}$ and $\mathrm{Mg} / \mathrm{Al}_{2} \mathrm{O}_{3}$ calcined at different temperatures-500 and $650{ }^{\circ} \mathrm{C}$.

Figure 6 shows the $X R D$ pattern of the used $\mathrm{Al}_{2} \mathrm{O}_{3}$ and $\mathrm{Mg} / \mathrm{Al}_{2} \mathrm{O}_{3}$ catalysts, which were collected from the furnace after the sequential catalytic decomposition of HFC-134a. The typical peak patterns of fresh $\mathrm{Al}_{2} \mathrm{O}_{3}$ catalysts were not observed in the XRD patterns of the spent catalysts, but the used $\mathrm{Al}_{2} \mathrm{O}_{3}$ catalysts revealed the typical XRD peak patterns of $\mathrm{AlF}_{3}\left(\right.$ at $25^{\circ}, 42^{\circ}, 52^{\circ}$, and $58^{\circ} 2 \theta$ [18]). This suggests that the $\mathrm{Al}_{2} \mathrm{O}_{3}$ catalysts were converted to $\mathrm{AlF}_{3}$ during the catalytic decomposition of HFC-134a over the $\mathrm{Al}_{2} \mathrm{O}_{3}$ catalysts. Based on the product distribution and the presence of $\mathrm{AlF}_{3}$, the decomposition mechanism of HFC-134a can be expressed using Equation (1) as follows:

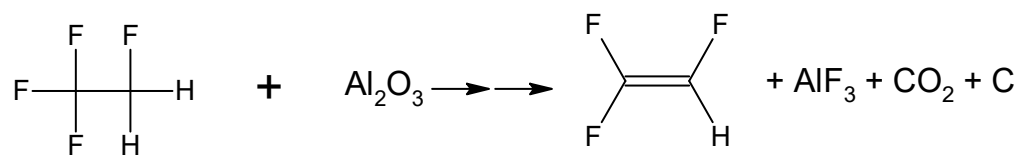




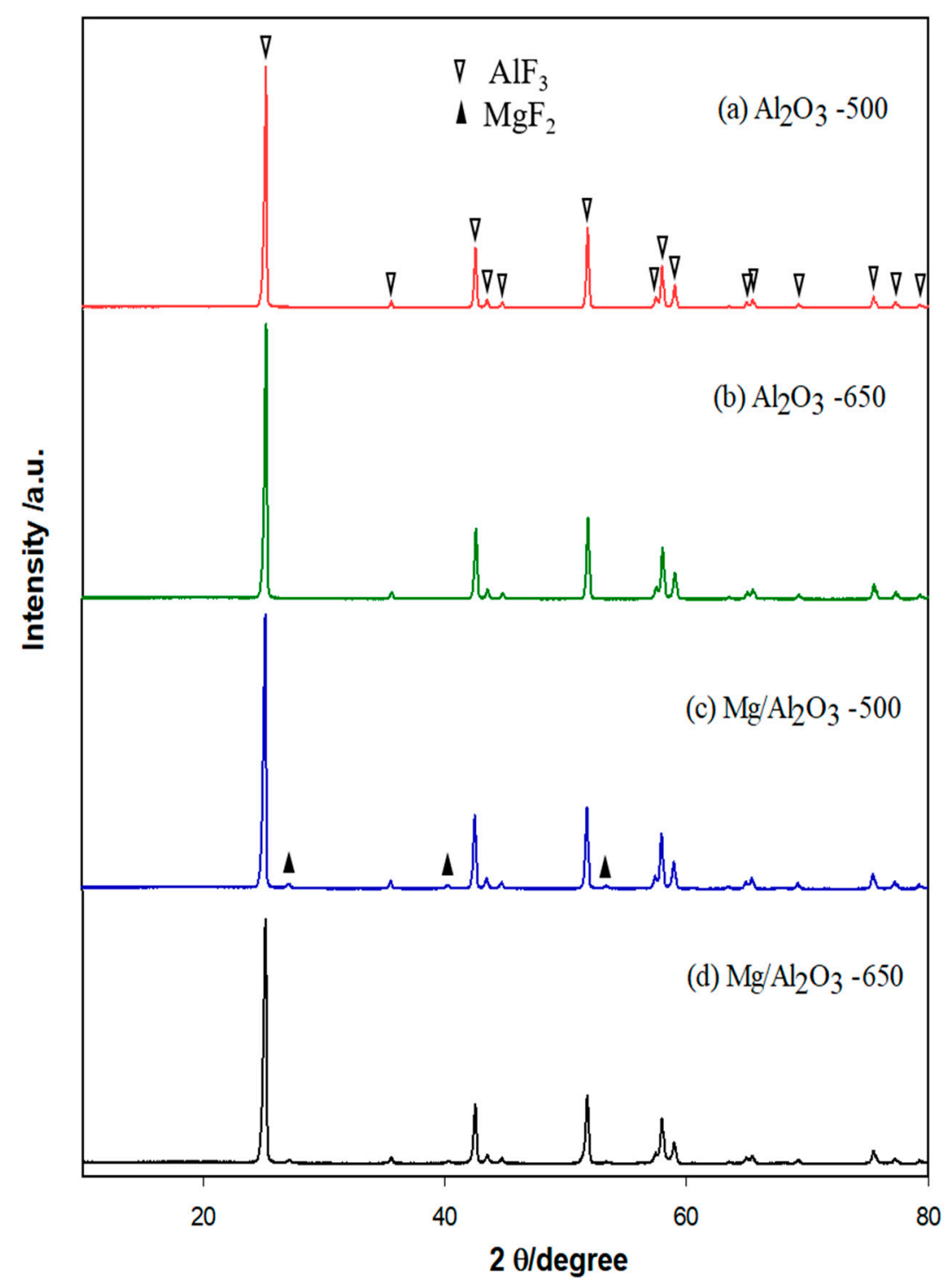

Figure 6. XRD pattern for the used $\mathrm{Al}_{2} \mathrm{O}_{3}$ and $\mathrm{Mg} / \mathrm{Al}_{2} \mathrm{O}_{3}$.

When $\mathrm{Mg} / \mathrm{Al}_{2} \mathrm{O}_{3}$ catalysts were used, the typical peaks of $\mathrm{MgF}_{2}$ were also observed on the XRD pattern of the used $\mathrm{Mg} / \mathrm{Al}_{2} \mathrm{O}_{3}$ catalysts (at $24^{\circ}, 42^{\circ}$, and $52^{\circ} 2 \theta[16]$ ), as shown in Figure $7 \mathrm{c}, \mathrm{d}$. This suggests that $\mathrm{Mg}$ was also directly involved in the defluorination reaction of HFC-134a according to the following reaction:

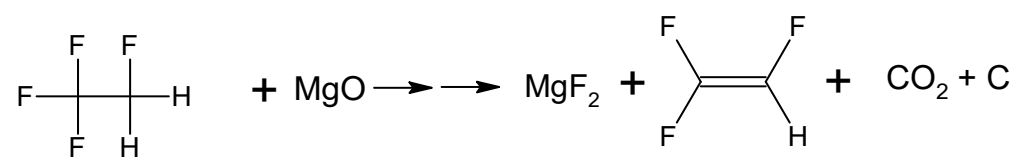

Figure 7 depicts the rate of $\mathrm{CO}_{2}$ formation during the catalytic decomposition of HFC-134a over $\mathrm{Al}_{2} \mathrm{O}_{3}$ and $\mathrm{Mg} / \mathrm{Al}_{2} \mathrm{O}_{3}$ catalysts. The $\mathrm{Mg} / \mathrm{Al}_{2} \mathrm{O}_{3}$ catalysts produced a higher rate of TrFE formation than the $\mathrm{Al}_{2} \mathrm{O}_{3}$ catalysts and a smaller level of $\mathrm{CO}_{2}$ production during the reaction. In addition, the $\mathrm{Mg} / \mathrm{Al}_{2} \mathrm{O}_{3}$ catalysts produced a smaller amount of coke than the $\mathrm{Al}_{2} \mathrm{O}_{3}$ catalysts. This can explain the increased number of weak Lewis acidic sites by $\mathrm{Mg}$ impregnation to $\mathrm{Al}_{2} \mathrm{O}_{3}$ catalysts, which can increase the relative ratio (Table 1 ) of weak acid sites compared to strong acidic sites that result in severe coke formation. The decreased coke formation over $\mathrm{Mg} / \mathrm{Al}_{2} \mathrm{O}_{3}-650$ compared with $\mathrm{Mg} / \mathrm{Al}_{2} \mathrm{O}_{3}-500$ 
confirmed that the relative number of strong acid sites is strongly related to catalyst deactivation during the catalytic decomposition of HFC-134a.

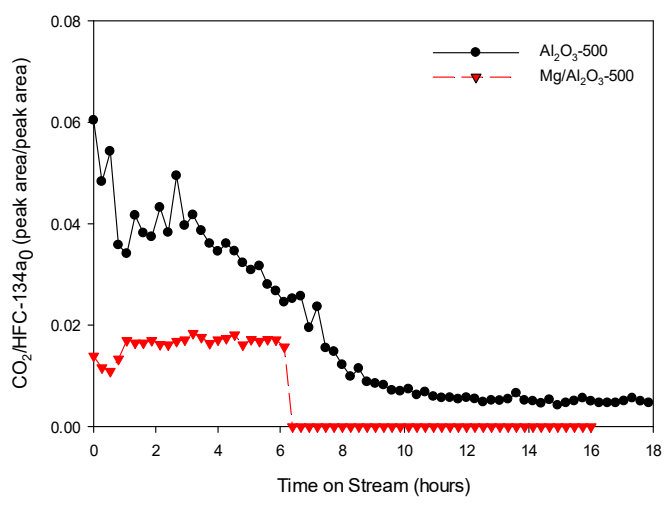

(a) $500{ }^{\circ} \mathrm{C}$

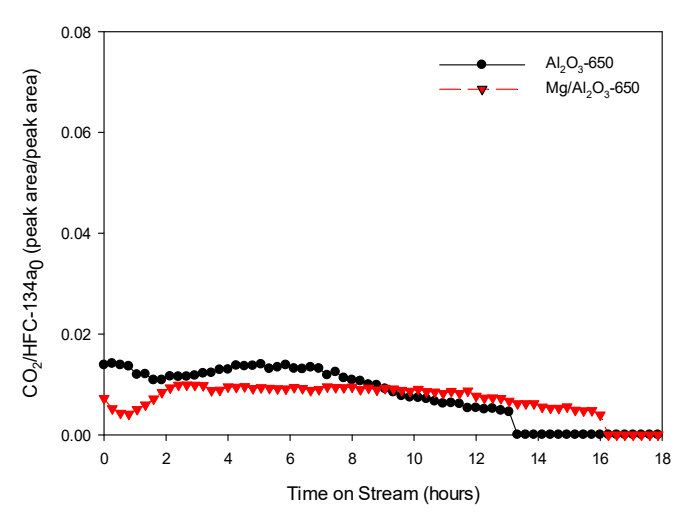

(b) $650{ }^{\circ} \mathrm{C}$

Figure 7. Formation rate of $\mathrm{CO}_{2}$ on the catalytic decomposition of HFC-134a over different catalysts calcined at different temperatures-500 and $650{ }^{\circ} \mathrm{C}$.

\section{Materials and Methods}

\subsection{HFC-134a and Catalysts}

Commercial HFC-134a was procured from RIGAS Co. Ltd., Daejeon, Republic of Korea, a gas manufacturer. Commercial $\mathrm{Al}_{2} \mathrm{O}_{3}$ and $5 \mathrm{wt} \% \mathrm{Mg} / \mathrm{Al}_{2} \mathrm{O}_{3}$ were obtained from Sasol. The catalysts were crushed and sieved to make small particles with a particle size between 1.0 and $1.7 \mathrm{~mm}$. Prior to the catalytic experiments, all catalysts were calcined at different temperatures-500 and $650{ }^{\circ} \mathrm{C}-$ for $2 \mathrm{~h}$ and categorized as $\mathrm{Al}_{2} \mathrm{O}_{3}-500, \mathrm{Al}_{2} \mathrm{O}_{3}-650, \mathrm{Mg} / \mathrm{Al}_{2} \mathrm{O}_{3}-500$, and $\mathrm{Mg} / \mathrm{Al}_{2} \mathrm{O}_{3}-650$, respectively. The $\mathrm{BET}$ surface area and pore volume of each catalyst were measured using a BET analyzer (Micromeritics 3Flex). $\mathrm{NH}_{3}$-TPD analysis and XRD of the catalysts were performed using the same procedure reported elsewhere [38,39].

\subsection{HFC-134a Decomposition Test}

The efficiency of the catalysts on the catalytic decomposition of HFC-134a was examined by VPFR-GC/MS, as shown in Figure 8. The VPFR-GC/MS system consisted of a gas supply, reactor, HF trap, and valve-GC/MS. For the catalytic decomposition of HFC-134a, $1.2 \mathrm{~g}$ of catalyst was taken in the catalyst bed, and $98 \mathrm{~mL} / \mathrm{min}$ of $\mathrm{N}_{2}$ gas and $2 \mathrm{~mL} / \mathrm{min}$ of HFC- $134 \mathrm{a}$ gas $\left(2 \%\right.$ of HFC- $\left.134 \mathrm{a} / \mathrm{N}_{2}\right)$ was supplied to the system. After the stabilization of the system, a temperature of $600{ }^{\circ} \mathrm{C}$ was set and the catalytic decomposition began. The gas hourly space velocity (GHSV) and weight hourly space velocity (WHSV) of the system were $1667 \mathrm{~h}^{-1}$ and $5000 \mathrm{~mL} \mathrm{~g}_{\text {cat }}{ }^{-1} \mathrm{~h}^{-1}$, respectively. The product gases emitted from the reactor were transferred to a valve GC/MS system (7890A/5975C inert, Agilent, Santa Clara, USA) via an HF trap containing CaO. Table 2 lists the detailed GC/MS conditions used in this study. The peaks on the GC/MS chromatogram were identified by comparing the mass spectrum of each peak on the chromatogram using an MS library (NIST 08th). The MS peak areas for all the components on the chromatogram were integrated to determine their relative amounts. The conversion rate (\%) of HFC-134a was calculated using Equation (3):

$$
\text { Conversion rate }(\%)=\left(1-\mathrm{A}_{\text {out }} / \mathrm{A}_{\text {in }}\right) \times 100
$$

where $A_{i n}$ is the peak area of HFC-134a in the reactant gas, and $A_{\text {out }}$ is the peak area of HFC-134a in the product gas. 


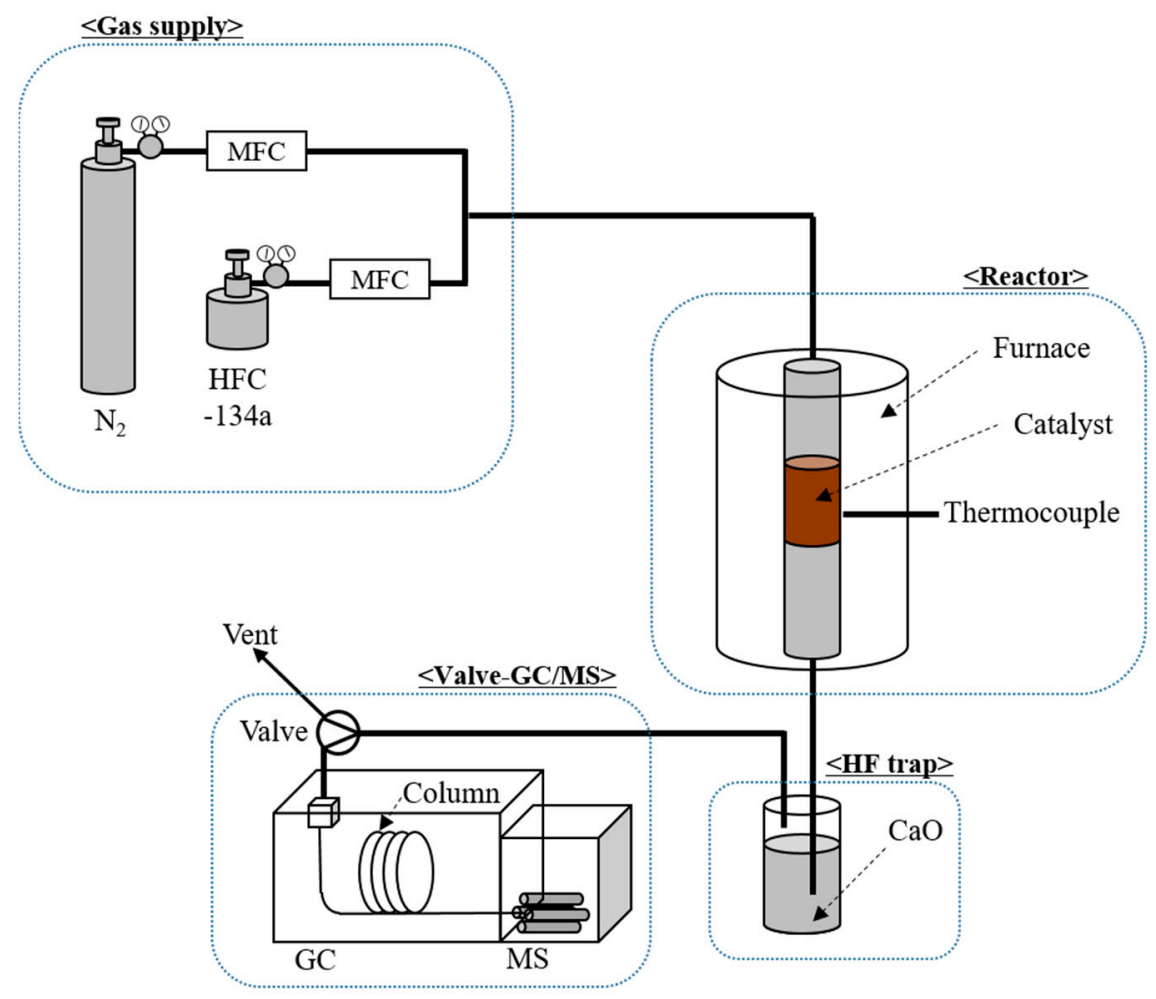

Figure 8. Vertical plug flow reactor-gas chromatography/mass spectrometry (VPFR-GC/MS) system used in this study.

Table 2. GC/MS condition.

\begin{tabular}{cccc}
\hline & GC & \multicolumn{2}{c}{ MS } \\
\hline Inlet & $260^{\circ} \mathrm{C}$, split ratio $50: 1$ & Ion source & $230{ }^{\circ} \mathrm{C}$ \\
Column & GS-GASPRO, $60 \mathrm{~m}$ length $\times 0.32 \mathrm{~mm}$ inner diameter & Quadrupole filter & $150^{\circ} \mathrm{C}$ \\
Oven & $50{ }^{\circ} \mathrm{C} \rightarrow 20^{\circ} \mathrm{C} / \mathrm{min} \rightarrow 260^{\circ} \mathrm{C}$ & Scan range & $\mathrm{m} / \mathrm{z} 17 \sim 600$ \\
\hline
\end{tabular}

\section{Conclusions}

The catalytic decomposition and conversion of HFC-134a was successfully carried out using $\mathrm{Al}_{2} \mathrm{O}_{3}$ and $\mathrm{Mg} / \mathrm{Al}_{2} \mathrm{O}_{3}$ at $600{ }^{\circ} \mathrm{C}$ by calcinating the catalysts at 500 and $650{ }^{\circ} \mathrm{C}$. The use of $\mathrm{Mg} / \mathrm{Al}_{2} \mathrm{O}_{3}$ and an increase in calcination temperature led to a higher HFC-134a decomposition efficiency. Compared with $\mathrm{Al}_{2} \mathrm{O}_{3}, \mathrm{Mg} / \mathrm{Al}_{2} \mathrm{O}_{3}$ had a larger BET surface area and higher weak Lewis acidity and basicity. The relative number of strong acidic sites in $\mathrm{Al}_{2} \mathrm{O}_{3}$ and $\mathrm{Mg} / \mathrm{Al}_{2} \mathrm{O}_{3}$ also decreased with increasing calcination temperature from 500 to $650{ }^{\circ} \mathrm{C}$, which led to a decrease in the amount of coke formation and increased the lifetime of the catalyst. TrFE, known for being valuable, was obtained as a by-product and its yield was higher over $\mathrm{Mg} / \mathrm{Al}_{2} \mathrm{O}_{3}$.

Supplementary Materials: The following are available online at http://www.mdpi.com/2073-4344/9/3/270/s1, Figure S1: Carbon dioxide-temperature programmed desorption $\left(\mathrm{CO}_{2}-\mathrm{TPD}\right)$ curves of $\mathrm{Al}_{2} \mathrm{O}_{3}$ and $\mathrm{Mg} / \mathrm{Al}_{2} \mathrm{O}_{3}$ calcined at different temperatures-500 and $650^{\circ} \mathrm{C}$.

Author Contributions: Conceptualization, C.M.A.S., S.J., Y.-K.P., Y.-M.K., and S.K.; Funding acquisition, S.K.; Investigation, M.S. and A.A.; Supervision, S.J. and S.K.; Writing - original draft, C.M.A.S.; Writing - review \& editing, Y.-K.P., Y.-M.K., and S.K.

Funding: This research was supported by Hallym University Research Fund (HRF-201809-007).

Conflicts of Interest: The authors declare no conflict of interest. 


\section{References}

1. GISTEMP Team. GISS Surface Temperature Analysis (GISTEMP), NASA Goddard Institute for Space Studies. Available online: https:/ / data.giss.nasa.gov/gistemp/ (accessed on 2 November 2018).

2. Hansen, J.; Ruedy, R.; Sato, M.; Lo, K. Global surface temperature change. Rev. Geophys. 2010, 48, 1-29. [CrossRef]

3. Srinivasan, J. Climate Change Greenhouse gases and Aerosols. Resonance 2008, 13, 1146-1155. [CrossRef]

4. Solomon, S.; Qin, D.; Manning, M.; Chen, Z.; Marquis, M.; Averyt, K.B.; Tignor, M.; Miller, H.L. (Eds.) IPCC Climate Change 2007: The Physical Science Basis. Contribution of Working Group I to the Fourth Assessment Report of the Intergovernmental Panel on Climate Change; Cambridge University Press: Cambridge, UK, 2007; p. 996.

5. Richter, R.D.; Ming, T.; Davies, P.; Liu, W.; Caillol, S. Removal of non- $\mathrm{CO}_{2}$ greenhouse gases by large-scale atmospheric solar photocatalysis. Prog. Energy Combust. Sci. 2017, 60, 68-96. [CrossRef]

6. Montreal Protocol- Achievements to Date and Challenges Ahead. Available online: http://ozone.unep.org/ en/focus / montreal-protocol-achievements-date-and-challenges-ahead (accessed on 2 November 2018).

7. Franklin, J. The atmospheric degradation and impact of 1,1,1,2-tetrafluoroethane (Hydrofluorocarbon 134a). Chemisphere 1993, 27, 1565-1601. [CrossRef]

8. UNFCCC 1998. The Kyoto Protocol to the United Nations Framework Convention on Climate Change. Available online: https:/ / unfccc.int/resource/docs/convkp/kpeng.pdf (accessed on 2 November 2018).

9. Kigali Amendment to the Montreal Protocol. Available online: https:/ / eia-international.org/wp-content/ uploads/EIA-Kigali-Ammendment-to-the-Montreal-Protocol-FINAL.pdf (accessed on 2 November 2018).

10. Shiojiri, K.; Yanagisawa, Y.; Yamasaki, A.; Kiyono, F. Separation of F-gases (HFC-134a and SF 6 ) from gaseous mixtures with nitrogen by surface diffusion through a porous Vycor glass membrane. J. Membr. Sci. 2006, 282, 442-449. [CrossRef]

11. Sanders, D.F.; Smith, Z.P.; Guo, R.; Robeson, L.M.; McGrath, J.E.; Paul, D.R.; Freeman, B.D. Energy-efficient polymeric gas separation membranes for a sustainable future: A review. Polymer 2013, 54, 4729-4761. [CrossRef]

12. Mie, T.; Han, J.; He, X.; Qin, L. Investigation of HFC-13a Decomposition by combustion and its kinetic characteristics in a laboratory scale reactor. Environ. Prot. Eng. 2015, 41, 43-150.

13. Ohm, T.I.; Chae, J.S.; Moon, S.H. Numerical and Experimental Study on the Destruction of Waste Refrigerant (HFCs) in Incinerator. J. Korea Soc. Waste Manag. 2016, 33, 454-460. [CrossRef]

14. Watanabe, T.; Tsuru, T. Water plasma generation under atmospheric pressure for HFC destruction. Thin Solid Films 2008, 516, 4391-4396. [CrossRef]

15. Iizuka, A.; Ishizaki, H.; Mizukoshi, A.; Noguchi, M.; Yamasaki, A.; Yanagisawa, Y. Simultaneous Decomposition and Fixation of F-Gases Using Waste Concrete. Ind. Eng. Chem. Res. 2011, 50, 11808-11814. [CrossRef]

16. Jia, W.; Liu, M.; Lang, X.; Hu, C.; Li, J.; Zhu, Z. Catalytic dehydrofluorination of 1,1,1,2-tetrafluoroethane to synthesize trifluoroethylene over a modified $\mathrm{NiO} / \mathrm{Al}_{2} \mathrm{O}_{3}$ catalyst. Catal. Sci. Technol. 2015, 5, 3103-3107. [CrossRef]

17. Takita, Y.; Tanabe, T.; Ito, M.; Ogura, M.; Muraya, T.; Yasuda, S.; Nishiguchi, H.; Ishihara, T. Decomposition of $\mathrm{CH}_{2} \mathrm{FCF}_{3}$ (134a) over Metal Phosphate Catalysts. Ind. Eng. Chem. Res. 2002, 41, 2585-2590. [CrossRef]

18. Han, T.U.; Yoo, B.S.; Kim, Y.M.; Hwang, B.A.; Sudibya, G.L.; Park, Y.K.; Kim, S. Catalytic conversion of 1,1,1,2-tetrafluoroethane (HFC-134a). Korean J. Chem. Eng. 2018, 35, 1611-1619. [CrossRef]

19. Han, W.; Chen, Y.; Jin, B.; Liu, H.; Yu, H. Catalytic hydrolysis of trifluoroethane over alumina. Greenh. Gases 2014, 4, 121-130. [CrossRef]

20. Song, J.Y.; Chung, S.H.; Kim, M.S.; Seo, M.G.; Lee, Y.H.; Lee, K.Y.; Kim, J.S. The catalytic decomposition of $\mathrm{CF}_{4}$ over $\mathrm{Ce} / \mathrm{Al}_{2} \mathrm{O}_{3}$ modified by cerium sulphate precursor. J. Mol. Catal. 2013, 370, 50-55. [CrossRef]

21. Li, G.L.; Nashiguchi, H.; Ishihara, T.; Moro-oka, Y.; Takita, Y. Catalytic dehydrofluorination of $\mathrm{CF}_{3} \mathrm{CH}_{3}$ (HFC143a) into $\mathrm{CF}_{2} \mathrm{CH}_{2}$ (HFC1132a). Appl. Catal. 1998, 16, 309-317. [CrossRef]

22. Iung, E.; Jeon, S.; Kim, C.U.; Jeong, S.Y.; Park, Y.K.; Jeon, J.K. Hydro-upgrding of n-octadecane over $\mathrm{Pt}-\mathrm{Mg} / \mathrm{HY}$ catalysts. Catal. Today 2016, 265, 124-130.

23. Jeon, S.H.; You, Y.; Jin, H.; Kim, C.U.; Park, Y.K.; Lee, C.H.; Jeon, J.K. Hydroupgrading of bio-oil over PtMg/KIT-6 catalysts. J. Nanosci. Nanotechnol. 2019, 19, 1126-1129. [CrossRef] 
24. Lu, J.; Zhao, Z.; Xu, C.; Duan, A.; Zhang, P. Effects of Calcination Temperature on the Acidity and Catalytic Performances of HZSM-5 Zeolite Catalysts for the Catalytic Cracking of n-Butane. J. Nat. Gas Chem. 2005, 14, 213-220.

25. Tribalis, A.; Panagiotou, G.D.; Bourikas, K.; Sygellou, L.; Kennou, S.; Ladas, S.; Lycourghiotis, A.; Kordulis, C. Ni Catalysts supported on Modified Alumina for Diesel Steam Reforming. Catalysts 2016, 6, 11. [CrossRef]

26. Novakovic, T.B.; Rozic, L.S.; Petrovic, S.P.; Vukovic, Z.M.; Mitric, M.N. Study of the effect of Mg(II) addition and annealing conditions on the structure of mesoporous aluminum oxide using Plackett-Burman design. J. Serb. Chem. Soc. 2015, 80, 1-14. [CrossRef]

27. Nakrela, A.; Benramdane, N.; Bouzidi, A.; Kebbab, Z.; Medles, M.; Mathieu, C. Site location of Al-dopant in $\mathrm{ZnO}$ lattice by exploiting the structural and optical characterization of $\mathrm{ZnO}: \mathrm{Al}$ thin films. Results Phys. 2016, 6, 133-138. [CrossRef]

28. Wagih, A. Effect of $\mathrm{Mg}$ addition on mechanical and thermoelectrical properties of $\mathrm{Al}^{-} \mathrm{Al}_{2} \mathrm{O}_{3}$ nanocomposite. Trans. Nonferrous Met. Soc. China 2016, 26, 2810-2817. [CrossRef]

29. Souza, J.J.N.; Meireles, B.R.L.A.; Cordeiro, A.M.T.M.; Santos, I.M.G.; Maria, A.S. Iron-doped Alfa-Alumina applied in the degradation of phenol solutions. Rev. Virtual Quim. 2017, 9, 2539-2550. [CrossRef]

30. Matori, K.A.; Wah, L.C.; Hashim, M.; Ismail, I.; Mohd Zaid, M.H. Phase transformations of $\alpha$-Alumina made from waste Aluminium via a precipitation technique. Int. J. Mol. Sci. 2012, 13, 16812-16821. [CrossRef]

31. Xu, X.; Sun, L.; Wang, Y. $\mathrm{NF}_{3}$ decomposition over $\mathrm{Al}_{2} \mathrm{O}_{3}$ reagents without water. J. Nat. Gas Chem. 2011, 20, 418-422. [CrossRef]

32. Gandhi, M.S.; Mok, Y.S. Effect of packing materials on the decomposition of tetrafluoroethane in a packed bed dielectric barrier discharge plasma reactor. Int. J. Environ. Sci. Technol. 2015, 12, 499-506. [CrossRef]

33. Jia, W.; Wu, Q.; Lang, X.; Hu, C.; Zhao, G.; Li, J.; Zhu, Z. Influence of Lewis Acidity on Catalytic activity of the porous Alumina for dehydrofluorination of 1,1,1,2-tetrafluoroethane to Trifluoroethylene. Catal. Lett. 2015, 145, 654-661. [CrossRef]

34. Meng, B.C.; Sun, Z.Y.; Ma, J.P.; Cao, G.P.; Yuan, W.K. Selective Liquid-phase Hydrodechlorination of Chlorotrifluoroethylene over Palladium-Supported Catalysts: Activity and Deactivation. Catal. Lett. 2010, 138, 68-75. [CrossRef]

35. Ohnishi, R.; Wang, W.L.; Ichikawa, M. Selective hydrodechlorination of CFC-113 on Bi- and Tl-modified palladium catalysts. Appl. Catal. A-Gen. 1994, 113, 29-41. [CrossRef]

36. Scott, S.P.; Sweetman, M.; Thomson, J.; Fitzegerald, A.G.; Sturrocky, E.J. Catalytic Hydrogenolysis of 1,1,2-Trichlorotrifluoroethane on $\gamma-\mathrm{Al}_{2} \mathrm{O}_{3}$-Supported Palladium/Zinc Oxide Catalyst. J. Catal. 1997, 168, 501-510. [CrossRef]

37. Mori, T.; Yasuoka, T.; Morikawa, Y. Hydrodechlorination of 1,1,2-trichloro-1,2,2-trifluoroethane (CFC-113) over supported ruthenium and other noble metal catalysts. Catal. Today 2004, 88, 111-120. [CrossRef]

38. Niwa, M.; Katada, N.; Sawa, M.; Murakami, Y. Temperature-Programmed Desorption of Ammonia with Readsorption based on the derived theoretical equation. J. Phys. Chem. 1995, 99, 8812-8816. [CrossRef]

39. Speakman, S.A. Introduction to X-Ray Powder Diffraction Data Analysis; Technical Report; Center for Materials Science and Engineering at MIT: Cambridge, MA, USA, 2009; pp. 19-20.

(C) 2019 by the authors. Licensee MDPI, Basel, Switzerland. This article is an open access article distributed under the terms and conditions of the Creative Commons Attribution (CC BY) license (http:/ / creativecommons.org/licenses/by/4.0/). 